Utah State University

DigitalCommons@USU

\title{
Urban Bias in Price Risk: The Geography of Food Price Distributions in Low-Income Economies
}

Christopher B. Barrett

Utah State University

Follow this and additional works at: https://digitalcommons.usu.edu/eri

\section{Recommended Citation}

Barrett, Christopher B., "Urban Bias in Price Risk: The Geography of Food Price Distributions in LowIncome Economies" (1995). Economic Research Institute Study Papers. Paper 54.

https://digitalcommons.usu.edu/eri/54

This Article is brought to you for free and open access by the Economics and Finance at DigitalCommons@USU. It has been accepted for inclusion in Economic Research Institute Study Papers by an authorized administrator of DigitalCommons@USU. For more information, please contact digitalcommons@usu.edu.

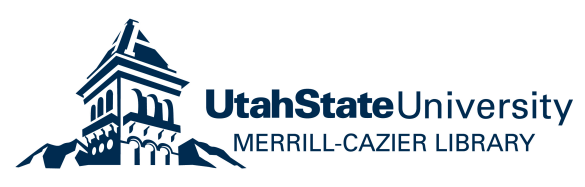




\section{Economic Research Institute Study Paper ERI \#95-05}

URBAN BIAS IN PRICE RISK: THE GEOGRAPHY OF FOOD PRICE DISTRIBUTIONS IN LOW-INCOME ECONOMIES

By

Christopher B. Barrett

\section{DEPARTMENT OF ECONOMICS \\ UTAH STATE UNIVERSITY \\ LOGAN, UTAH}

April 1995 


\title{
URBAN BIAS IN PRICE RISK: THE GEOGRAPHY OF FOOD PRICE DISTRIBUTIONS IN LOW-INCOME ECONOMIES
}

\author{
Christopher B. Barrett, Assistant Professor \\ Department of Economics \\ Utah State University \\ Logan, UT 84322
}

The analyses and views reported in this paper are those of the author(s). They are not necessarily endorsed by the Department of Economics or by Utah State University.

Utah State University is committed to the policy that all persons shall have equal access to its programs and employment without regard to race, color, creed, religion, national origin, sex, age, marital status, disability, public assistance status, veteran status, or sexual orientation.

Information on other titles in this series may be obtained from: Department of Economics, Utah State University, 3530 Old Main Hill, Logan, Utah 84322-3530.

Copyright (C) 1995 by Christopher B. Barrett. All rights reserved. Readers may make verbatim copies of this document for noncommercial purposes by any means, provided that this copyright notice appears on all such copies. 


\title{
URBAN BIAS IN PRICE RISK: THE GEOGRAPHY OF \\ FOOD PRICE DISTRIBUTIONS IN \\ LOW-INCOME ECONOMIES
}

\author{
Christopher B. Barrett
}

\begin{abstract}
The geography of agricultural marketing has important implications for the stochastic distribution of agricultural commodity prices. This paper proposes that objective food price risk differs between rural and urban areas of infrastructure-poor economies characterized by spatially concentrated patterns of foodgrains storage. This difference implies an urban bias having adverse welfare effects for peasants who seasonally switch between net food seller and net food buyer positions. Empirical analysis of rice price data from Madagascar suggests that price variability and skewness indeed differ between rural and urban areas in ways that adversely influence the relative welfare of rural peasants.
\end{abstract}




\title{
Urban Bias In Price Risk: \\ The Geography Of Food Price Distributions In Low-Income Economies
}

\author{
Christopher B. Barrett
}

April 1995

The author is an assistant professor in the Department of Economics, Utah State University, Logan, UT 84322-3530 USA. The financial support of the Institute for the Study of World Politics and the Social Science Research Council are gratefully acknowledged. This work has benefitted considerably from conversations with Jean-Paul Chavas, Michael Carter and Matt Holt, but they are by no means implicated in this project. 


\section{Urban Bias In Price Risk: \\ The Geography Of Food Price Distributions In Low-Income Economies}

The geography of agricultural marketing has important implications for the stochastic distribution of agricultural commodity prices. This paper proposes that objective food price risk is experienced differently in rural and urban areas of economies characterized by spatially concentrated patterns of foodgrains storage. These differences imply an urban bias, in that they generate adverse welfare effects for peasants who seasonally switch between net food seller and net food buyer positions. Empirical analysis of rice price data from Madagascar suggests that price variability and skewness indeed differ between rural and urban areas in ways that adversely influence the relative welfare of rural peasants.

This paper considers the proposition that objective food price risk ${ }^{1}$ is experienced differently in rural and urban areas of economies characterized by spatially concentrated patterns of foodgrains storage. The principal finding is that in infrastructure-poor countries rural and urban price distributions predictably diverge in such a way that rural residents face greater objective food price risk than do urban residents. Since greater risk exposure reduces the welfare of risk averse individuals, the geography of food prices has adverse welfare effects on the rural peasantry. This suggests an important dimension to urban bias thus far ignored, with potentially actionable policy remedies having relatively minimal distortions to the rest of the food economy.

If commercial storage of storable food commodities such as basic grains is concentrated in urban areas, as is true in most low-income economies, grain often flows from rural to urban areas in the immediate post-harvest period but reverses direction as the harvest approaches again 
and rural farm households exhaust stocks and become food buyers. Although this phenomenon is common, its impact on the variance or skewness of rural and urban food price distributions has thus far been ignored. ${ }^{2}$ But if the higher-order moments of food price distributions faced by particular subpopulations systematically exceed those faced by others, this alone will generate important welfare differences between risk averse agents.

One can usefully distinguish between three distinct subpopulations. First there are yearround net food buyers, a group including all non-producers of food, and thus most urban residents. Second, there are year-round net food sellers, mainly large commercial farmers. Finally, there is a class of peasants who predictably switch between net seller and net buyer positions over the course of the agricultural calendar, selling in the immediate post-harvest period and buying in the pre-harvest "hungry season." Recent research indicates that a large proportion of farmers engage in such seasonal switching of exchange relations - from seller to purchaser, then back again [Ellsworth and Shapiro, 1989]. Indeed in Africa, a substantial proportion of food producers are net food buyers in aggregate [Weber et al., 1988; Budd, 1993; Barrett and Dorosh, 1995 ]. It is this latter group, whose preferences over the moments of food price distributions vary seasonally, ${ }^{3}$ that shoulders most of the burden of the geography of food marketing in infrastructure-poor countries, and I follow the literature on urban bias [Lipton, 1977; Bates, 1981] in focusing primarily on this peasant class.

The above points are developed over three sections. Section I presents (informally) a theoretical explanation of rural-urban differences in food price distributions. Section II presents corroborating empirical evidence from rice in Madagascar. Section III offers policy and research implications. 


\section{Interseasonal and Intraseasonal Supervariability and Superskewness in Rural Food Prices}

Because all people consume food, but only some buy or sell it, food prices affect the welfare of everyone, but not in identical ways. Those who sell food enjoy welfare gains from higher expected food prices, while those who purchase food prefer lower mean prices. This follows directly from Roy's Identity. Moreover, since people consume food over many periods and food production involves biological lags, food prices are inevitably subject to considerable temporal uncertainty. Except under the rare circumstances when the strong assumption of agent risk neutrality is defensible, one must thus consider agents' preferences with respect to moments beyond the mean (e.g., variance, skewness), as well. Any form of risk aversion implies a preference for low variability in real income, and thus in prices. ${ }^{4}$ Agents' qualitative preferences with respect to skewness, however, vary across agents according to their net buyer/seller position. Purchasers are harmed by the extraordinary price rises that yield positive skewness in price series, while sellers lose from sharp price drops associated with negative skewness [Menezes, Geiss and Tressler, 1980]. Fortunately for sellers, a workably competitive storage market tends to ensure positive skewness in commodity prices series [Williams and Wright, 1991; Deaton and Laroque, 1992]. Net sellers thus prefer high means, low variance and positive skewness, while net buyers desire low means, low variance and negative skewness in food price series.

Based on these rather parsimonious descriptions of agents' preferences, one can rank order price distributions' welfare effects using the concept of stochastic dominance. One distribution, A, dominates another distribution, B, stochastically if an expected utility maximizer would always prefer A to B [Anderson, Dillon and Hardaker, 1977; Whitmore and Findlay, 
1978]. There are different degrees of stochastic dominance, corresponding to different assumptions about agents' risk preferences. Section II defines these explicitly and employs stochastic dominance techniques to test empirically the hypothesis of urban bias in rice price risk in Madagascar. Stochastic dominance is the sense in which I will claim that urban food price distributions arewelfare superior to rural distributions for peasants who routinely switch from net sellers to net buyers as the crop season progresses.

Rural smallholders with seasonally-varying preferences over the moments of food price distributions systematically suffer from the geography of agricultural marketing prevailing in most low-income countries. First, they tend to receive lower mean sales prices over the course of the year than do other food sellers. Peri-urban farmers enjoy higher prices during the postharvest period when rural smallholders sell, while the rural large farmers are more likely to sell during the pre-harvest price peaks when smallholders become purchasers. Second, assuming identical price risk aversion across agents, rural smallholders face greater welfare-reducing price variability than their urban brethren. Third, while rural large farmers often sell during the hungry season, thereby benefitting from positive skewness in prices, smallholders are usually hungry season food buyers. Moreover, rural purchasers face more sharply positive hungry season food price skewness than do urban buyers. These propositions with respect to mean, variance and skewness derive from the concepts of interseasonal and intraseasonal supervariability and superskewness in rural food prices, introduced next.

Basic grains storage tends to be concentrated in urban areas of developing economies for multiple reasons. Greater population density and higher per capita incomes concentrate purchasing power in urban areas. Moreover, following Hotelling [1929], marketing is generally 
even more spatially concentrated than demand. Rural-urban infrastructure differences magnify this tendency toward spatially concentrated marketing. The effect of low rural electrification rates, poor rural roads maintenance, unreliable rural communications, and sparse, illiquid rural financial networks is transactions and capital costs that are generally higher in rural areas, reinforcing the inherent spatial concentration of marketing services. Higher rural operating costs demand a higher rate of return to rural commercial storage (i.e., interseasonal price variation).

Just as the geography of food marketing and storage has a sound basis in economic theory, so does this geography have implications for rural and urban food price distributions. First, mean rural food prices are below mean urban prices in the immediate post-harvest period, but increase more rapidly as the year progresses, eventually exceeding mean urban prices during the pre-harvest hungry season, before the cycle recommences with the next harvest. Since rural seasonal prices exhibit lower minima and higher maxima than urban seasonal prices, one might classify this phenomenon "interseasonal supervariability" in rural food prices, where the prefix "super-" indicates the ordinal ranking of rural measures against an urban base.

Second, the same conditions that generate a concentration of interseasonal grains storage in urban areas -- higher costs and lower and less concentrated demand -- also serve to thin rural markets, especially in the hungry season. The fewer the participants, the less elastic is aggregate demand and supply. Because storage is more distant from rural markets, lag times in response by arbitraging intermediaries tend to be greater, fuelling price variability. Moreover, if small market size and some minimum efficient scale to commercial storage result in high concentration ratios, incumbent rural middlemen with market power might rationally stimulate food price volatility to discourage entry [Newbery, 1978; Hollander, 1994]. Whether due to market 
thinness, lags in trader responses, intermediary market power, or some combination, rural food price variability may be greater not only interseasonally, but also intraseasonally, especially in the hungry season. For consistency's sake, label this hypothesis "intraseasonal supervariability" in rural food prices.

Finally, the nonnegativity constraint inherent to grains storage implies asymmetry in storable commodities' price distributions [Williams and Wright, 1991; Deaton and Laroque, 1992]. Real food price data generally exhibit flat ranges punctuated by upward spikes that tend to emerge and dissipate rapidly. However, the regional differences in transactions costs and communications efficiency that facilitate urban concentration of commercial food storage also inhibit rapid response by arbitragers that might mitigate the duration and intensity of upward price spikes in rural areas, which are of course most likely during the hungry season. As a result, the positive skewness of prices is likely to be greatest in rural areas during the hungry season. Call this hypothesized phenomenon hungry season "superskewness" in rural food prices.

Figure 1 depicts these three hypothesized phenomena - interseasonal and intraseasonal supervariability and hungry season superskewness. Interseasonal supervariability is evident in the steeper slope of the rural conditional expectation function. Comparison of the rural and urban conditional price distributions reveals intraseasonal supervariability and hungry season superskewness. If true, these hypothesized phenomena imply a strong urban bias in the distribution of objective price risk in low-income economies.

Strictly speaking, interseasonal supervariability need not represent any risk, for if each period's price distribution is degenerate (i.e., variance equals zero) one can forecast intertemporal price patterns perfectly. The issue is instead individuals' ability to smooth 
Figure 1: Schematic of Rural and Urban Conditional Food Price Distributions

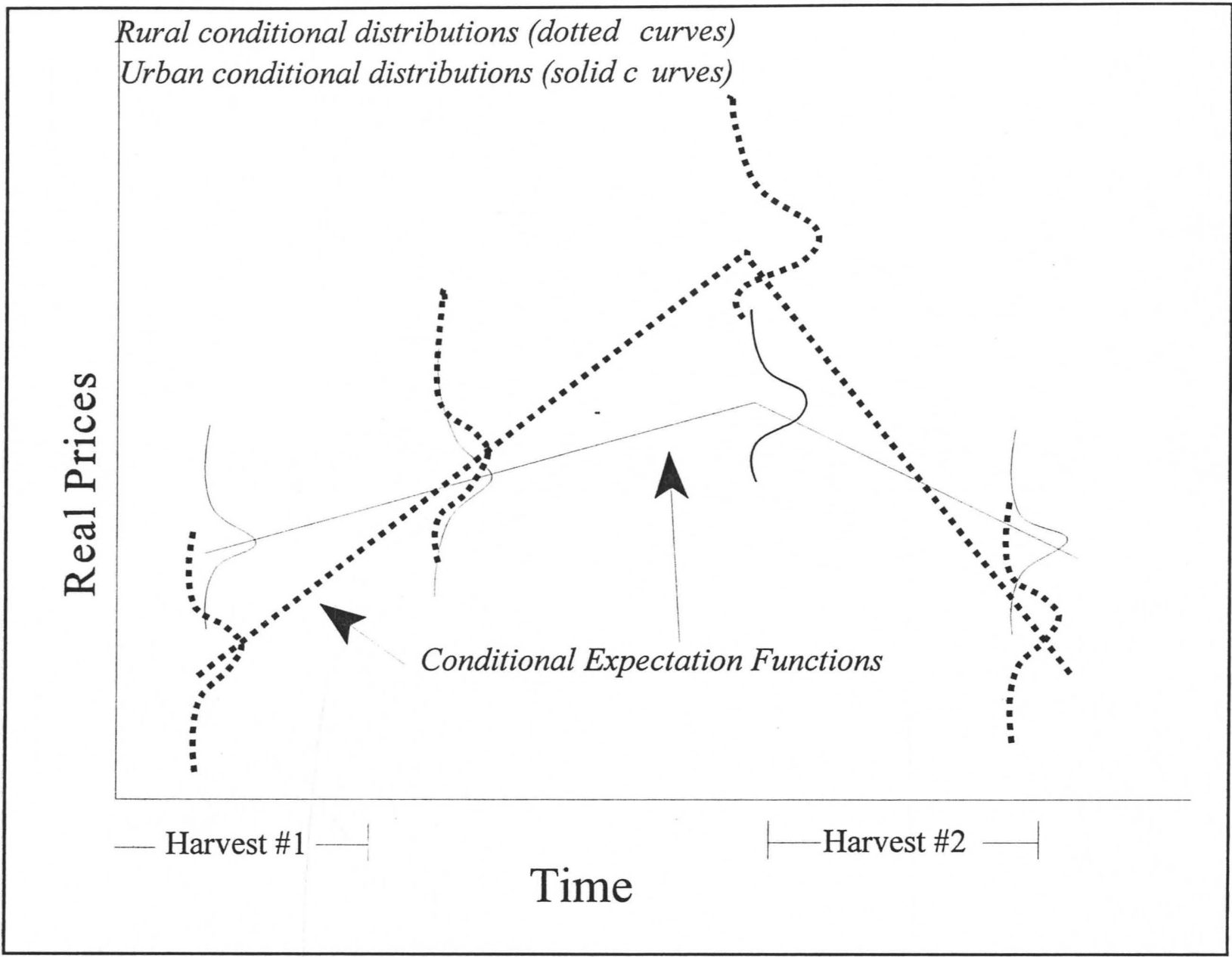

consumption optimally through savings and credit. Interseasonal variation in food prices, especially when negatively correlated with nominal income, induces savings and borrowing to smooth consumption [Deaton, 1990]. If interseasonal food price variability is greatest in rural areas, the need for financial intermediation is likewise greatest in rural regions. Although considerable evidence exists that consumption smoothing occurs through savings [Deaton, 1992; Paxson, 1993], rural financial networks are notoriously underdeveloped relative to urban networks. No comparative empirical evidence exists, but it seems likely that greater demand 
for intertemporal transactions due to interseasonal supervariability conspires with tighter rural credit constraints to inhibit rural consumption smoothing, relative to that of urbanites. If this is true, the geography of agricultural marketing and finance jointly impose welfare costs on rural residents not borne by their urban counterparts. ${ }^{5}$

Intraseasonal supervariability implies that a price risk-averse agent would prefer to face the urban price series than its contemporaneous rural counterpart. Unless the urban mean is substantially lower when such an agent is selling or higher when the agent is buying - which will not be the case under interseasonal supervariability in rural prices - the urban price series is welfare-superior in a (second degree) stochastic dominance sense.

Similar results obtain with respect to hungry season superskewness if a downside risk averse agent purchases food: s/he would uniformly prefer to face the urban food price distribution than the rural distribution, assuming equal mean and variance. Note that large farmers with net sales of food in all periods gain from positive skewness in food prices; this represents upside welfare risk to sellers. But positive skewness in price is unattractive to downside risk averse smallholders who are seasonal net buyers. Hungry season superskewness in rural food prices may thus imply welfare differences between wealthy (all-season net seller) and poor (hungry season net buyer) farmers, as well as between urban and rural net food buyers.

\section{Rural-Urban Rice Price Distributions in Madagascar}

I test the hypotheses of interseasonal and intraseasonal supervariability and hungry season superskewness in rural food prices using regional rice price data from Madagascar. This is not meant as a definitive set of statistical tests, but merely an empirical corroboration of the 
plausibility of the concepts mapped out above. Rice is the staple food throughout Madagascar, comprising more than half of all cultivated land [MPARA/FAO, 1988]. Although rice production is the nation's main economic activity, an estimated 63 percent of Malagasy rice producers are net rice buyers [Barrett and Dorosh, 1995]. Both private and public agricultural marketing networks are designed around the movement of paddy or processed rice, predominantly in hulled form [Abt Associates, 1991], with 50-75 percent of national commercial grains storage concentrated in just three urban areas: the capital city, Antananarivo, and the port cities of Toamasina and Mahajanga [Cabinet Fivoarana, 1989]. The human and physical geography of rice marketing in the peasant-farming dominated economy of Madagascar thus fits well the stylizations of the previous section.

The data are monthly retail-level observations, January 1983 to December 1991, of nominal hulled rice prices from 17 Madagascar's agricultural enumeration regions. Barrett [1994a] explains the data in detail. For each regional series, year-specific seasonal indexes, $s_{\text {it }}$, were computed using the ratio-to-moving average method, a simple non-parametric technique yielding index numbers that are the ratio of the price observation, $\mathrm{p}_{\mathrm{it}}$, to a twelve-month centered moving average, price, $\mathrm{m}_{\mathrm{it}}$ ( $\mathrm{i}$ indexes region, $\mathrm{t}$ indexes time).

$$
\begin{aligned}
& s_{i t}=\frac{p_{i t}}{m_{i t}} \cdot 100 \\
& m_{i t}=\frac{1}{2}\left(\frac{1}{12} \sum_{j=-5}^{6} p_{i t \cdot j}+\frac{1}{12} \sum_{k=-6}^{5} p_{i t+k}\right)
\end{aligned}
$$

This removes the trend and cyclical variation from the regional time series, leaving just the seasonal and stochastic components, thereby accomodating demand and supply shocks associated 
with region-specific economic cycles and inflation patterns, so one need not impose national indicators across a range of demonstrably heterogeneous sub-economies. ${ }^{6}$

Since the hypotheses to be tested compare the moments of rural and urban price series, we next group the specific seasonals geographically and calculate the empirical moments of seasonally disaggregated group frequency distributions. The urban group comprises the three metropolitan regions with most of the nation's commercial grains storage capacity (Antananarivo, Mahajanga, Toamasina). The other 14 regions constitute the rural group. These two regional price distributions are similarly centered: sample mean panseasonal price in the two groups differs by less than one percent, a statistically insignificant amount. The peak of Madagascar's rice harvest runs from mid-March to late June. The soudure (hungry season) runs November through early March. Six bimonthly distributions were constructed for each areal grouping. ${ }^{7}$

The three detailed hypotheses generated by section I are that for the distinct rural and urban conditional price distributions, $r(p \mid t)$ and $u_{t}(p \mid t)$, respectively,
(1) $\quad \sigma_{\mathrm{r}}^{2}>\sigma_{\mathrm{u}}^{2}$
interseasonal supervariability
(2) $\quad \sigma_{r, t}^{2}>\sigma_{u, t}^{2}$
intraseasonal supervariability
(3) $\sigma_{r, t}^{3}>\sigma_{u, t}^{3} \forall t \in H$
hungry season superskewness

where $\sigma^{\mathrm{i}}$ is the $\mathrm{i}^{\mathrm{th}}$ central moment of the price distribution, and $\mathrm{H}$ is the set of hungry season months. The computed empirical moments of Madagascar's urban and rural bimonthly rice price distributions support these hypotheses (Table 1). Interseasonal supervariability is evident in the greater range of rural seasonal means ${ }^{-}(87.3-110.8)$ than urban seasonal means (90.4- 
Table 1: Seasonal Hulled Rice Price Distributions

\begin{tabular}{|c|c|c|c|c|}
\hline & Mean & $\begin{array}{l}\text { Std. } \\
\text { Dev. }\end{array}$ & C.V. ${ }^{a}$ & $\begin{array}{l}\text { Relative } \\
\text { Skewness }\end{array}$ \\
\hline \multicolumn{5}{|l|}{$\frac{\text { Urban series }}{(n=48 / \text { period }):}$} \\
\hline Jan-Feb & 109.8 & $12.5^{*}$ & 0.114 & $0.3 *$ \\
\hline Mar-Apr & 107.1 & $14.9 *$ & 0.139 & $0.4^{*}$ \\
\hline May-Jun & 93.2 & 13.6 & 0.146 & $0.1^{*}$ \\
\hline Jul-Aug & 90.4 & $7.2 *$ & 0.080 & $-0.2 *$ \\
\hline Sep-Oct & 96.1 & 12.9 & 0.134 & 0.5 \\
\hline Nov-Dec & 100.5 & $12.1^{*}$ & 0.129 & $0.3 *$ \\
\hline panseasonal & 99.5 & $14.4^{*}$ & 0.145 & 0.7 \\
\hline \multicolumn{5}{|l|}{$\begin{array}{l}\frac{\text { Rural series }}{(n=224 / \text { period })} \\
:\end{array}$} \\
\hline Jan-Feb & 110.8 & $16.9 *$ & 0.152 & $1.2 *$ \\
\hline Mar-Apr & 105.2 & $18.7^{*}$ & 0.177 & $1.2 *$ \\
\hline May-Jun & 87.3 & 12.9 & 0.148 & $0.9 *$ \\
\hline Jul-Aug & 89.7 & $11.7 *$ & 0.131 & $0.5^{*}$ \\
\hline Sep-Oct & 99.5 & 14.2 & 0.143 & 0.1 \\
\hline Nov-Dec & 106.1 & $14.4^{*}$ & 0.136 & $0.9 *$ \\
\hline panseasonal & 99.8 & $17.2^{*}$ & 0.172 & 0.8 \\
\hline
\end{tabular}

${ }^{a}$ standard deviation/mean $\quad{ }^{\mathrm{b}}$ skewness/standard deviation ${ }^{3}$

* rural-urban difference statistically significant at the five percent level. 
109.8), as well as in the higher variance and coefficient of variation of panseasonal rural prices. Average interseasonal returns to storage are 25 percent higher in rural areas than urban. Intraseasonal supervariability appears in the higher coefficients of variation for each bimonthly rural price distribution, and in rural variance greater than urban variance in all periods except the peak harvest months of May-June, when rural markets are flush with intermediaries. Hungry season superskewness is apparent in the substantially greater positive relative skewness in rural prices during the peak of the hungry season, November-February. Most of these differences are statistically significant at the five percent level. Since the difference in rural and urban panseasonal means is less than one percent, the essential difference between the rural and urban rice price distributions is the greater objective price risk faced by rural inhabitants.

This greater objective price risk exposure of peasants can be demonstrated mostly unambiguously through stochastic dominance testing of the general hypothesis that risk-averse peasants are worse off facing the rural price distribution than if they could face the urban price distribution. Stochastic dominance is an especially useful method of risk analysis under the expected utility hypothesis when one has incomplete information about agents' preferences [Anderson, Dillon and Hardaker, 1977; Whitmore and Findlay, 1978]. If net seller agents' utility is increasing in income, he will unambiguously prefer the urban conditional price distribution, $u(p \mid t)$, to the rural one, $r(p \mid t)$ if and only if

$$
\begin{aligned}
& D^{N S}{ }_{1}\left(p_{j} \mid t\right)=\Sigma_{p i \leq p j} g\left(p_{i}\right)-\Sigma_{p i \leq p j} f\left(p_{i}\right) \geq 0 \forall p_{j} \\
& j=1, \ldots, n, \text { and } p_{j} \in \text { non-negative integers\} }
\end{aligned}
$$

In words, if the cumulative mass function for the discrete distribution $r(p \mid t)$ lies everywhere to the left of the cumulative mass function for the discrete distribution $u(p \mid t), u(p \mid t)$ offers 
everywhere better (i.e., higher) prices. If this condition holds, $u(p \mid t)$ first-degree stochastic dominates (FDSD) $r(p \mid t)$. Conversely for a net buyer,

$$
\begin{aligned}
& D^{N B}{ }_{1}\left(p_{j} \mid t\right)=\Sigma_{p i \leq p j} f\left(p_{i}\right)-\Sigma_{p i \leq p j} g\left(p_{i}\right) \geq 0 \forall p_{j} \\
& j=1, \ldots, n, \text { and } p_{j} \in \text { non-negative integers\} }
\end{aligned}
$$

Only then does $u(p \mid t)$ present everywhere better (i.e., lower) prices than $r(p \mid t)$.

If one is willing to impose a bit more structure on agents' preferences, specifically risk aversion, then the more powerful concept of second-degree stochastic dominance (SDSD) becomes available. A risk-averse net seller will prefer $u(p \mid t)$ to $r(p \mid t)$ if and only if

$$
\begin{aligned}
& D^{N S}{ }_{2}\left(p_{j} \mid t\right)=\Sigma_{p i \leq p j} D^{N S}{ }_{1}\left(p_{i-1} \mid t\right) \geq 0 \forall p_{j} \\
& j=1, \ldots, n, \text { and } p_{j} \in \text { non-negative integers }
\end{aligned}
$$

Conversely, for a net buyer,

$$
\begin{aligned}
& D^{N B}{ }_{2}\left(p_{j} \mid t\right)=\Sigma_{p i \leq p j} D^{N B}{ }_{1}\left(p_{i-1} \mid t\right) \geq 0 \forall p_{j} \\
& j=1, \ldots, n, \text { and } p_{j} \in \text { nnon-negative integers\} }
\end{aligned}
$$

With these definitions in place, it should be apparent that SDSD provides an appropriate test of the general hypothesis of this paper, that the urban conditional price distribution welfare dominates the rural conditional price distribution for risk-averse peasants who seasonally switch between net seller and net buyer positions.

If we assume that Malagasy peasants are net rice sellers from the beginning of the harvest in March, and that they are net buyers for at least the last two months of the hungry season (January-February), the data indeed indicate $u(p \mid t)$ dominates $r(p \mid t)$ in a second-degree stochastic sense. Figures 2 and 3 show this for two illustrative plots of the rural and urban conditional cumulative mass functions: the hungry season period of January-February (Figure 
2) and the post-harvest period of May-June (Figure 3). Formally, $D^{N B}{ }_{2}\left(p_{j} \mid t\right) \geq 0 \forall p_{j}$ for $t=J A N-$ FEB and $D^{N S}{ }_{2}\left(p_{j} \mid t\right) \geq 0 \forall p_{j}$ for $t=M A R-A P R, M A Y-J U N$, and JUL-AUG. So only during the last four months of the calendar year, during the transition from the post-harvest period to the hungry season, do urban rice price series not stochastically dominate rural rice price series for risk averse peasants.
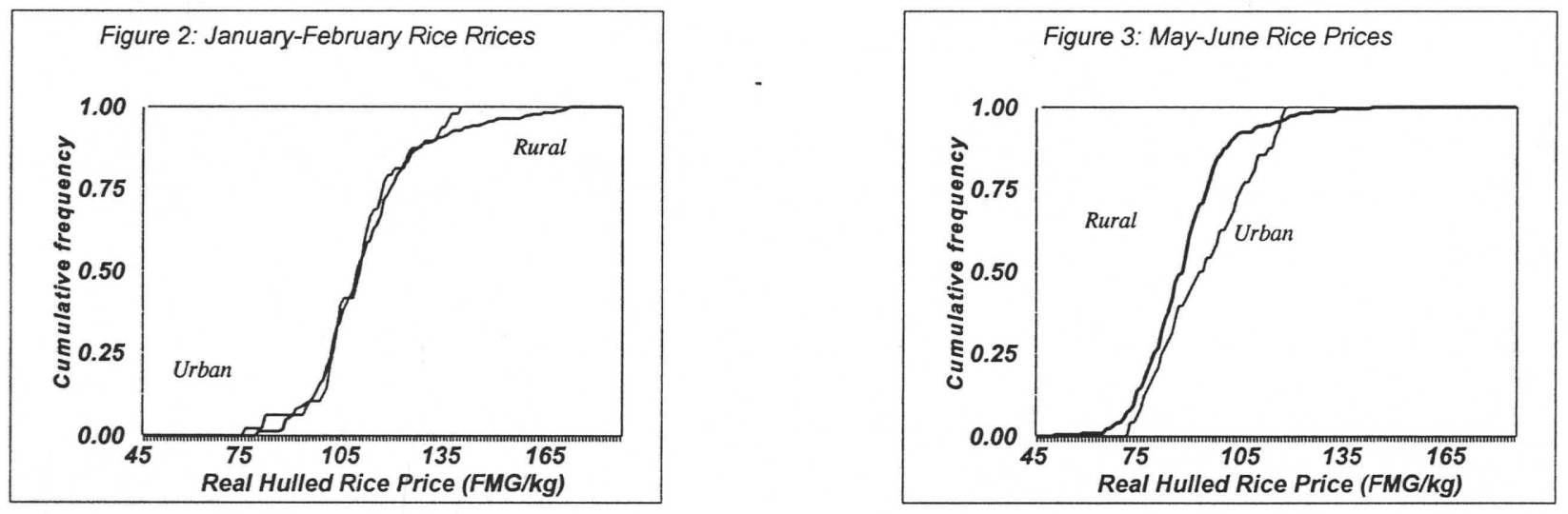

\section{Implications For Policy and Research}

The broad message of this paper is that the geography of agricultural marketing in lowincome countries results in greater objective food price risk being borne by rural residents than city-dwellers. Peasants who seasonally switch between net food seller and net food buyer positions are particularly disadvantaged by the price distributions that follow naturally from food marketing patterns. Because food price distributions have predictable spatial and temporal patterns, disaggregation across both space and time is thus essential to careful food price analysis. Price data averaged over space and time (e.g., annual national averages) may mask trends of substantial importance to policy design and research on agricultural marketing and production, food security and poverty. 
The results presented here have a clear policy implication. High gross rates of return to commercial storage often reflect high real transactions costs that are inversely related to the quality of human and physical infrastructure. Even in competitive rural markets, interseasonal and intraseasonal supervariability and hungry season superskewness of rural food prices emerge naturally where infrastructure is poor. This likely impacts adversely on the welfare and food security of credit-constrained net buyer subpopulations, a group increasingly recognized as numerous in low-income countries. While government controls on marketing margins cannot rectify the problem [Unnevehr 1985], redressal of the root geographic cause of these phenomena may generate substantial social returns. Research suggests rural public works projects have important effects on demand, supply and food prices when interseasonal flow reversals stem from physical infrastructure deficiencies, with generally favorable consequences for rural consumption, employment, investment and agricultural production [Ahmed and Donovan, 1992].

The present findings add to the evidence that rural infrastructure investment can have important positive direct welfare effects on poor peasant populations. Moreover, positive indirect effects may be considerable, as well, in that higher risk generally leads to lower rates of private investment, creating a sort of vicious circle wherein lower private investment in marketing infrastructure leads to high price variability which further discourages market development. The prospective "crowding in" effects of public investment in rural communications, transport and utilities networks might thus operate not just by increasing expected returns to private investment, but by dampening the variability of returns to investment as well by dampening price risk. Since investment tends to be an important leading variable in employment creation, and rural labor markets are an important component of the portfolio of 
income-generating activities for rural peasants, not to mention landless rural subpopulations, rural infrastructure provision may have important indirect welfare effects as well through improving investment incentives.

There are two econometric implications worth remarking on as well. Considerable attention has been paid to the relationship between food quality and expenditures, both by those striving for accurate estimation of price elasticities [Deaton 1988] and those concerned about the effect of income growth or transfers on nutrient intake levels [Pitt, 1983; Behrman and Deolalikar, 1987]. Cross-sectional expenditure surveys typically gather recall data from clusters of households. While spatial variation in prices (due to transportation costs, for example) is admitted, within-cluster variation in unit values (expenditures divided by physical quantities) is generally attributed to measurement error and variation in the quality of food purchases. Imputed quality variation might be substantially overstated. Where recall periods are more than just a matter of days, there may be substantial temporal variation in price as well. Since wealthier agricultural households generally wait longer after harvest before entering the market as food purchasers, and because food prices rise from harvest due to storage costs, there may be a genuine positive correlation in rural expenditure surveys between wealth or income and average food prices that is unrelated to any differences in the quality of food purchased. Attribution of within-cluster price variability to quality differences will thus tend to bias estimates of the relationship between income and food quality upwards, and to bias "qualityadjusted" estimates of the income elasticity of nutrient demand downwards.

Finally, recent in advances in time series analysis have admitted modelling autocorrelated heteroskedasticity in commodity price estimation using ARCH/GARCH techniques [e.g., 
Aradhyula and Holt, 1988; Holt and Aradhyula, 1990; Jayne and Myers, 1994; Barrett, 1994b]. Table 1 suggests and Barrett [1994b] confirms autoregressive heteroskedasticity's presence in food price series from Madagascar. This is likely a widespread phenomenon that development researchers should begin to give more attention, especially by those concerned with agricultural price and marketing policy. Moreover, the evidence here suggests that generalization to conditional skewness would be fruitful as well, in that there seems to be a dynamic dimension to skewness that existing methods do not capture well. This is especially important if downside risk aversion matters to economic agents and is routinely addressed through government interventions to defend price bands, ceilings and floors. Recent advances in generalizing autocorrelation across the moments of stochastic distributions [Hansen, 1994] might thus be of interest to development researchers exploring the welfare consequences of food price policies. 


\section{NOTES}

1. Objective price risk is measurable and ignores interpersonal differences in risk preferences and information access or utilization (e.g., Bayesian updating).

2. Timmer[1974], Southworth, Jones and Pearson[1979], Unnevehr [1985], Elz [1987], and Loveridge [1991] have reflected on the effects of interseasonal flow reversals on mean regional prices, but not on any moments beyond the mean.

3. This seasonal-switching accentuates that sharp qualitative variation within the agricultural sector in farmers' interests regarding food price policy can generate rich coalitional dynamics in the political economy of food price policy [Barrett, 1995].

4. Preferences with respect to the variability of food prices are actually analytically more ambiguous than preferences with respect to income[Finkelshtain and Chalfant, 1991; Barrett, 1995]. While it is beyond the scope of this paper to develop this point rigorously, the core analytical result is that agents are risk averse with respect to variability in a commodity's price when either their livelihood or their diet depend on that commodity. For expositional purposes I simply assume this to be true of Malagasy peasants, although it invariably holds for at least the critical poorest and wealthiest subclasses.

5. Also, there are often greater food substitution possbilities in urban areas, mitigating urban consumers' real income risk exposure due to food price variability.

6. One would, for instance, prefer not to rely on the national consumer price index (CPI) to deflate these series since the Malagasy CPI is based on a 1968-69 household expenditure survey fielded only in the capital city.

7. The empirical moments from monthly and quarterly distributions were also computed, at the cost of degrees of freedom (most serious for the urban series) and facility in separating the post-harvest and soudure periods, respectively. The alternative specifications yielded qualitatively identical results to those in Table 1, so the findings appear robust for this data. 


\section{REFERENCES}

Abt Associates, 1991. 'The Rural Marketing System in Madagascar.' Antananarivo:USAID.

Ahmed, R. and C. Donovan, 1992, Issues of Infrastructural Development: A Synthesis Of The Literature, Washington: International Food Policy Research Institute.

Anderson, J.R., J.L. Dillon and J.B. Hardaker, 1977, Agricultural Decision Analysis, Ames, IA: Iowa State University Press.

Aradhyula, S.V. and M.T. Holt, 1988, 'GARCH Time-Series Models: An Application to Retail Livestock Prices,' Western Journal of Agricultural Economics, vol. 13, no. pp. 365-74.

Barrett, C.B, 1994a, 'Peasants, Prices and Markets in Madagascar: Toward An Understanding Of Agricultural Supply Response To Liberalization In A Smallholder Economy,' Ph.D. dissertation, University of Wisconsin-Madison.

Barrett, C.B., 1994b, 'The Impacts of Agricultural Liberalization on Commodity Price Distributions: Evidence From Madagascar,' University of Wisconsin-Madison Department of Agricultural Economics Staff Paper number 380.

Barrett, C.B., 1995, 'The Microeconomics of Coalition Alignments: Some Insights on Food Price Policy,' Utah State University Economics Research Institute Study Paper \#95-01.

Barrett, C.B. and P.A. Dorosh, 1995, 'Farmers' Welfare and Changing Food Prices: Nonparametric Evidence From Rice in Madagascar,' Cornell University Food and Nutrition Policy Program working paper.

Bates, R.H., 1981, Markets and States in Tropical Africa, Berkeley: University of California Press.

Behrman, J.R. and A.B. Deolalikar, 1987, 'Will Developing Country Nutrition Improve With Income? A Case Study For Rural South India,' Journal of Political Economy, vol. 95 pp.: 492-507.

Cabinet Fivoarana, 1989, 'Etude Des Problèmes De Stockage De Céreales,' Antananarivo: Ministère de la Production Agricole et de la Réforme Agraire.

Deaton, A, 1988, 'Quality, Quantity, and Spatial Variation of Price,'American Economic Review vol. 78, pp.418-430.

Deaton, A., 1990, 'Saving in Developing Countries: Theory and Review.' Proceedings of the World Bank Annual Conference On Development Economics 1989. Washington: World Bank. 
Deaton, A., 1992, Understanding Consumption. Oxford: Clarendon Press.

Deaton, A. and G. Laroque, 1992, 'On the Behavior of Commodity Prices.' Review of Economic Studies vol. 59, pp. 1-23.

Ellsworth, L. and K. Shapiro, 1989, 'Seasonality in Burkina Faso Grain Marketing: Farmer Strategies and Government Policy,' in D.E. Sahn, editor, Seasonal Variability in Third World Agriculture, Baltimore: Johns Hopkins University Press.

Elz, D., editor, 1987, Agricultural Marketing Strategy and Pricing Policy. Washington: World Bank.

Finkelshtain, I. and J.A. Chalfant, 1991, 'Marketed Surplus Under Risk: Do Peasants Agree With Sandmo?' American Journal of Agricultural Economics, vol. 73, no.3, pp. 557-567.

Hansen, B.E., 1994'Autoregressive Conditional Density Estimation,' International Economic Review, vol. 35, no. 3, pp. 705-730.

Hollander, A, 1994, 'Noise: A firm-made trade barrier.' European Economic Review vol. 38, pp.133-141.

Holt, M.T. and S. V. Aradhyula, 1990, 'Price Risk in Supply Equations: An Application of GARCH Time-Series Models to the U.S. Broiler Market,' Southern Economic Journal vol. 57, pp. 230-242.

Hotelling, H, 1929, 'Stability in Competition.' Economic Journal vol. 39, pp. 41-57.

Jayne, T.S. and R. J. Myers, 1994, 'The Effect of Risk on Price Levels And Margins in International Wheat Markets,' Review of Agricultural Economics vol. 16, pp. 63-73.

Lipton, M., 1977, Why Poor People Stay Poor: Urban Bias in World Development, Cambridge: Harvard 'University Press.

Loveridge, S, 1991, 'Marketing in Rwanda.' Food Policy vol. 16, pp.95-104.

Menezes, C., C. Geiss and J. Tressler, 1980, 'Increasing Downside Risk.' American Economic Review vol. 70, no. 5, pp. 921-932.

Ministère de la Production Agricole Et De La Reforme Agraire and Food and Agriculture Organization of the United Nations, 1988, Projet Recensement National De L'Agriculture et Système Permanent Des Statistiques" Agricoles, 5 volumes. Antananarivo.

Newbery, D.M.G, 1978, 'Stochastic limit pricing.' Bell Journal of Economics vol. 9, pp. 260269. 
Paxson, C.H, 1993, 'Consumption and Income Seasonality in Thailand,' Journal of Political Economy vol. 101, pp. 39-72.

Pitt, M.M, 1983, 'Food Preferences And Nutrition In Rural Bangladesh.' Review of Economics and Statistics, vol. 65, pp. 105-114.

Southworth, V. R., W.O. Jones, and S. R. Pearson, 1979, 'Food Crop Marketing in Atebubu District, Ghana.' Food Research Institute Studies vol. 17, pp. 157-95.

Timmer, C.P, 1974, 'A Model of Rice Marketing Margins in Indonesia.' Food Research Institute Studies vol. 13, pp. 145-67.

Unnevehr, L.J, 1985, 'The Costs of Squeezing Marketing Margins: Philippine Government Intervention in Rice Markets,' The Developing Economies vol. 23, pp. 158-172.

Weber, M.T., J. M. Staatz, J.S. Holtzman, E.W. Crawford, and R.H. Bernsten, 1988, 'Informing Food Security Decisions in Africa; Empirical Analysis and Policy Dialogue,' American Journal of Agricultural Economics vol. 70, pp. 1044-1052.

Whitmore, G.A. and M.C. Findlay, 1978, Stochastic Dominance: An Approach to DecisionMaking Under Risk, Lexington, MA: Lexington Books.

Williams, J.C. and B.D. Wright, 1991, Storage and Commodity Markets. Cambridge: Cambridge University Press. 